\title{
VALORISATION OF EGG SHELL ASH AS A POTENTIAL REPLACEMENT FOR LIME IN STABILIZATION OF EXPANSIVE SOILS
}

\section{VREDENOVANJE PEPELA OD LJUSKE JAJETA KAO POTENCIJALNA ZAMENA KREČA U STABILIZACIJI EKSPANZIVNIH TLA}

\author{
Jijo JAMES \\ K. JOTHI PRIYA \\ P. KARTHIKA \\ S. KOKILA \\ V. VIDYASAGAR
}

\author{
ORIGINALNI NAUČNI RAD \\ ORIGINAL SCIENTIFIC PAPER \\ UDK:691.51 \\ 666.923 \\ doi:10.5937/GRMK2003013」
}

\section{INTRODUCTION}

Lime stabilization of expansive soils has been one of the oldest and most effective methods for improvement of poorly performing swelling soils. Addition of lime to expansive soils result in reduction in plasticity and swellshrink characteristics and improves strength of the stabilized soil [22]. However, a sift through literature reveals that lime stabilization has been found wanting under certain soil conditions like sulphate rich environments, conditions of alternate wetting and drying, freezing and thawing to name a few. In the recent years, a lot of focus has been put on the reuse of solid wastes in various streams of Civil Engineering for their effective management. Soil stabilization is one such avenue for effective reuse of solid wastes [16]. There have been a lot of investigations on the utilization of different types of solid wastes in soil stabilization. However, an effective replacement for lime is yet to be found despite its limitations. One pragmatic way of finding an effective replacement for lime is to adopt solid wastes similar to lime in chemical composition. Lime is an umbrella term adopted for quick lime $(\mathrm{CaO})$, hydrated lime $\left(\mathrm{Ca}(\mathrm{OH})_{2}\right)$ and carbonate lime $\left(\mathrm{CaCO}_{3}\right)$. Egg shell waste is one such waste material whose chemical composition is very similar to lime. The targeted egg production in India for the year 2020 is 106 billion [14]. Based on the calculation

\footnotetext{
Jijo James, AssociateProfessor in Civil Engineering, SSN

College of Engineering, Kalavakkam - 603 110, Tamil

Nadu, India; jijothegreat@gmil.com

K. Jothi Priya, P. Karthika, S. Kokila, V. Vidyasagar

Undergraduate in Civil Engineering, Tagore Engineering

College, Rathinamangalam, Chennai - 600127, India
}

done by James et al. [19], considering 5.5 grams of shell weight per egg, it is estimated that the annual generation of egg shell waste in India, by the end of 2020 will be 583,000 tonnes. This huge quantity can put a strain on the waste collection and management systems unless an effective reutilization method is not adopted. A lot of investigations have been carried out in the reutilization of egg shell waste in its powdered form in concrete as well as in soil engineering. Egg shells are primarily composed of calcium carbonate. Carbonate lime is not commonly adopted in soil stabilization as it is a chemically inert material and does not readily react with water [15]. One modified form of egg shell waste is egg shell ash (ESA). The chemical composition of ESA is very similar to quick lime [25] and can be potentially more reactive than egg shell powder. Very few investigations were found for the valorisation of this waste in soil stabilization despite its close similarity to quick lime in composition. Okonkwo et al. [25] researched the use of ESA along with cement in the stabilization of a lateritic soil. James and Pandian [17] studied the influence of ESA in improving the early strength of a lime stabilized expansive soil. Later, James et al.[19] investigated the effect of ESA as an auxiliary additive to lime in the stabilization of an expansive soil. Bensaifi et al.[4] delved into the mechanical properties of marl stabilized using combinations of Portland cement, blast furnace slag and ESA. Thus, it can be seen that very little work has been done in the use of a waste material that can be a potential replacement for lime in soil stabilization. This work attempted to investigate the capability of ESA as a replacement for lime for the stabilization of an expansive soil under normal as well conditions of alternate wetting and drying. 


\section{MATERIALS}

The various materials adopted in this investigation are the virgin swelling soil, industrial grade lime and ESA prepared from egg shell powder. The virgin swelling soil was investigated in the laboratory for its various geotechnical properties. The various properties of the soil that were investigated include liquid limit [11], plastic limit [11], shrinkage limit [7], grain size distribution [10], specific gravity [8], compaction characteristics [28], unconfined compression strength (UCS)[12], and classification [6]. All the tests were done in accordance with various codes of Bureau of Indian Standards (BIS). The geotechnical properties of the soil as determined through laboratory tests are given in Table 1. The chemical composition of the soil as well as the other materials, determined as a part of an earlier investigation [19] are shown in Table 2a. The industrial grade lime was sourced from M/s. Shiyal Chemicals, Chennai, India. The ESA was prepared by calcining egg shell powder obtained from M/s. SKM egg products, Erode, Tamil Nadu, India.

\section{METHODS}

The experimental investigation began with the preparation and characterization of the materials used in the investigation. It was followed by determination of initial consumption of lime (ICL), fixing of mix proportions, casting of UCS samples, simulation of wetting and drying, testing of specimens and determination of plasticity. Each stage of the experimental investigation has been explained in detail in the following subsections.

\subsection{Preparation and Characterization of Materials}

The investigation began with the preparation and characterization of materials. The soil was crushed and pulverized in the laboratory and sieved through the requisite sieves for the various tests based on BIS code [9]. Lime used in the investigation was used as obtained from the manufacturer without any preparation. The ESA was prepared from egg shell powder obtained from SKM egg products. The ESA was obtained by decomposition of the calcium carbonate in egg shells into calcium oxide by calcining the egg shell powder at a temperature of $500^{\circ} \mathrm{C}$ for a period of 3 hours [19]. After that, the ash was sieved through BIS 75-micron sieve for removal of any coarse unburnt particles that may have remained in the ash.

\subsection{Determination of ICL}

The initial consumption of lime may be defined as the minimum lime content required to raise the $\mathrm{pH}$ of the soil to 12.4 [2]. This value was obtained from the Eades and Grim $\mathrm{pH}$ test [13] done based on ASTM D6276 [2]. This is the minimum lime content required for the modification of soil properties. It is also referred to as lime modification optimum.

\subsection{Fixing of Mix Proportions}

After the determination of the ICL, the various proportions by which the lime content was to be substituted using ESA was fixed based on trial and error method. The ICL for the soil under investigation was $3 \%$. Table $2 b$ shows the various proportions selected for use in this investigation.

Table 1 Geotechnical Properties of Soil

\begin{tabular}{|l|l|}
\hline Property & Value \\
\hline Liquid limit $\left(w_{I}\right)$ & $66.9 \%$ \\
\hline Plastic limit $\left(w_{p}\right)$ & $27.1 \%$ \\
\hline Plasticity index $\left(I_{p}\right)$ & $49.8 \%$ \\
\hline Shrinkage limit $\left(w_{s}\right)$ & $9.2 \%$ \\
\hline Specific gravity $\left(G_{s}\right)$ & 2.75 \\
\hline Maximum dry density of the soil & $15.1 \mathrm{kN} / \mathrm{m}^{3}$ \\
\hline Optimum moisture content of the soil $\left(w_{o p t}\right)$ & $23.1 \%$ \\
\hline Unconfined compressive strength of soil $\left(q_{u}\right)$ & $82.4 \mathrm{kPa}$ \\
\hline Sand Content & $2.6 \%$ \\
\hline Silt Content & $65.2 \%$ \\
\hline Clay Content & $32.2 \%$ \\
\hline Classification & $\mathrm{CH}$ \\
\hline
\end{tabular}

Table 2a Chemical Composition of Soil, Lime and ESA

\begin{tabular}{|c|c|c|c|c|c|c|c|c|c|c|}
\hline Oxide (\%) & $\mathrm{Al}_{2} \mathrm{O}_{3}$ & $\mathrm{CaO}$ & $\mathrm{Fe}_{2} \mathrm{O}_{3}$ & $\mathrm{~K}_{2} \mathrm{O}$ & $\mathrm{MgO}$ & $\mathrm{Na}_{2} \mathrm{O}$ & $\mathrm{P}_{2} \mathrm{O}_{5}$ & $\mathrm{SiO}_{2}$ & $\mathrm{TiO}_{2}$ & $\mathrm{SO}_{3}$ \\
\hline Soil & 18.8 & 2.3 & 7.5 & 2.3 & 1.7 & 1.4 & 0.0 & 63.6 & 0.9 & 0.2 \\
\hline Lime & 0.4 & 81.1 & 0.1 & 0.0 & 3.2 & 8.0 & 0.2 & 4.7 & 0.0 & 2.3 \\
\hline ESA & 0.1 & 88.5 & 0.0 & 0.0 & 0.6 & 9.0 & 1.0 & 0.7 & 0.0 & 0.2 \\
\hline
\end{tabular}


Table $2 b$ Replacement Combinations of ESA for Lime

\begin{tabular}{|c|c|c|c|}
\hline Lime Content (\%) & ESA Content (\%) & \% Replacement & Designation \\
\hline 3 & 0 & 0 & LE30 \\
\hline 2 & 1 & 33.33 & LE21 \\
\hline 1.5 & 1.5 & 50 & LE1.5 \\
\hline 1 & 2 & 66.67 & LE12 \\
\hline 0 & 3 & 100 & LE03 \\
\hline
\end{tabular}

\subsection{Casting of Specimens}

Cylindrical specimens of dimensions $38 \mathrm{~mm} \times 76 \mathrm{~mm}$ were cast using a split mould using static compaction. The specimens were prepared at the maximum dry density and optimum moisture content of the soil determined from the compaction test. Three samples were cast for each of the combinations. The samples were demoulded and placed in sealed polythene covers until the specified curing period to prevent loss of moisture.

\subsection{Simulation of Wetting and Drying}

The samples prepared for wetting and drying were removed from the polythene bags after 28 days of curing and were subjected to cycles of wetting and drying. The samples were completely soaked in a bed of wet cotton for a period of 24 hours followed by air drying for a period of 24 hours. This constituted one cycle of wetting and drying. Different researchers have adopted different number of cycles in their investigations varying from three going up to twelve cycles ([26],[21],[1],[30],[23],[20]). The samples were subjected to one, three and five cycles of wetting and drying to determine the resistance of the sample to the loss in strength due to the extreme conditions.

\subsection{Sample Testing}

After the end of the designated curing period, the samples were removed from their covers and strained axially in a uniaxial loading frame of $40 \mathrm{kN}$ capacity. They were strained at a rate of $0.625 \mathrm{~mm} /$ minute until the samples failed. In the case of samples subjected to wetting and drying, the same procedure was followed on the samples, after the wetting and drying cycles.

\subsection{Determination of Plasticity}

The 28 days cured samples after failure were crushed and pulverized and sieved through the BIS 425 micron sieve and subjected to liquid limit and plastic limit tests to determine the effect of lime and ESA on the plasticity nature of the soil.

\section{RESULTS AND DISCUSSION}

The effect of lime and its replacement by ESA on the uniaxial strength, plasticity and resistance to wetting and drying has been discussed in detail in the following subsections.

\subsection{The Effect of Lime and ESA on the UCS}

Figure 1 shows the effect of lime and ESA on the UCS of the stabilized soil after 28 days of curing. The $3 \%$ lime stabilized soil specimen was considered as the control combination to compare the strengths of the modified specimens. It can be seen that the addition of lime has resulted in a very good improvement in strength. However, the replacement of lime with ESA in any proportion did not yield any improvement in strength of the soil. In fact, the addition of ESA in the stabilization process has resulted in the strength of the stabilized soil dropping by more than half of the control specimen. The strength of the lime stabilized soil was $309.8 \mathrm{kPa}$ whereas the strength of the other combinations are in the range of 95.6 to $128.7 \mathrm{kPa}$.

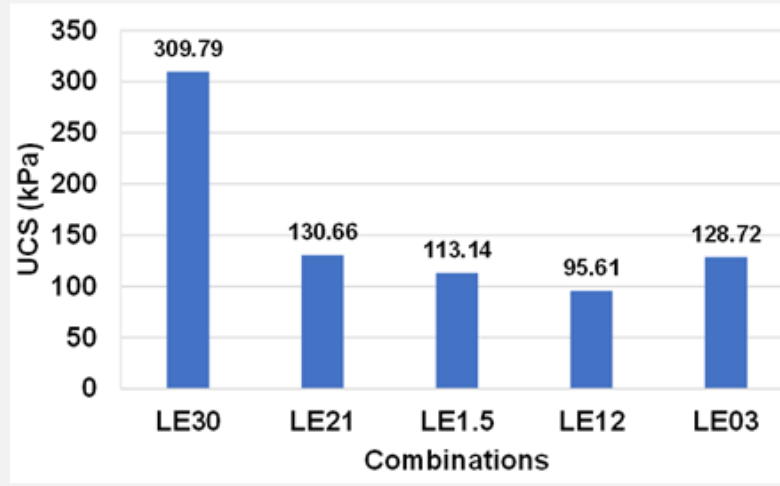

Figure 1 The Effect of Lime and ESA on the UCS of the Stabilized Soil

A comparison of the present study with similar earlier investigations was performed to check the beneficial effect of ESA addition. The investigations considered for comparison include the works done by James et al. [19] and James and Pandian [17]. The investigations were selected based on the similarity with the present study viz. use of combinations of lime and ESA in soil stabilization. To bring in the effect of the combination of lime and ESA, the two additives were reduced to a ratio as done in some earlier investigations ([18],[27]). However, pure lime and pure ESA combinations have not been included in the comparison. The UCS values of the ESA and lime stabilized soil specimens after 7 days of curing were compared. Figure 2 shows the comparison of the present study with earlier investigations. Therefore, it is clear that the strength gain in the present study was the lowest of all the three studies. However, it was very close to those obtained by James et al. [19]. The strength gain in the work reported by James and Pandian [17] was the highest. This may be due to the fact that high quality laboratory grade lime was used for the study. Moreover, when carefully considering these studies, only the present 
one adopted ESA as a replacement for lime whereas the other two studies adopted ESA as an auxiliary additive to lime. The minimum quantity of lime determined from the Eades and Grim pH test was present in the soil for stabilization in the other two studies. Investigations dealing with ESA as a partial replacement higher than ICL content could not be found in literature. Thus, based on the strength test results from figures 1 and 2, it can be stated that ESA as a replacement for lime is not a functional combination when minimum lime content required for stabilization is not present. Nasrizar et al. [24] state that there are three phases in the relation between strength and lime content viz. less than ICL (Phase 1), between ICL and optimum lime content (OLC) (Phase 2) and greater than OLC (Phase 3). The current investigation deals with lime content less than ICL when ESA replaces lime in the mix i.e. phase 1. Future investigations on whether ESA will be an effective replacement for lime should be investigated for phases two and three as well. The second major conclusion, that can be derived from the comparison is that lower ESA/lime ratios perform better in terms of strength gain when compared to higher ESA/lime ratio with the exception of one anomalous data point. It can be seen that ESA/lime ratio less than one gives higher strength results. Even comparing the present work with the work done by James et al. [19] which produced comparable strength results, it can be seen that lower ESA/lime ratios produced better strength.

Figure 3 shows the effect of curing period on the development of the strength of the stabilized soil. It can be seen that for the lime stabilized soil, there is a steady increase in the strength of the stabilized soil with increase in the curing period of the specimens. This is very much in agreement with earlier published works in lime stabilization ([22],[3]). However, in the case of the ESA modified specimens, with the exception of LE21, all the other specimens show a different trend of strength gain. All the combinations with the exception of LE21, show a dip in strength at 7 days of curing when compared to 3 days of curing. However, at 28 days of curing, there is a further increase in the strength. In the case of LE21, there is a very marginal but steady increase in strength of the stabilized soil from 3 days to 28 days of curing. This was in contrast with the results obtained by James et al. [19] as well as James and Pandian [17]. It is interesting to note that this happens in ESA modified combinations with ESA content either equal to or higher than lime content in the



Figure 2 Comparison of the Present Study with Earlier Works

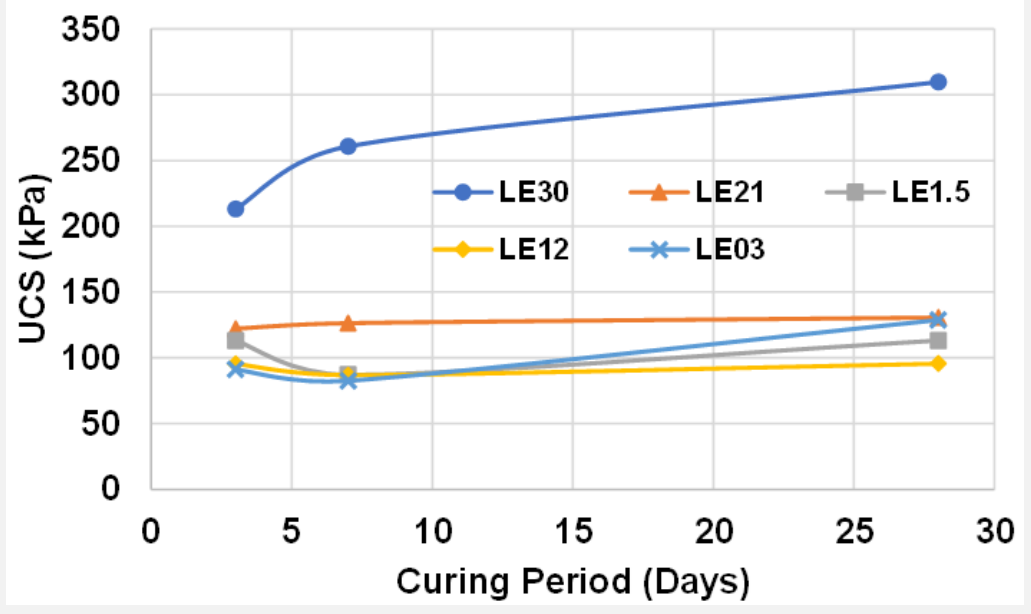

Figure 3 Development of UCS with Curing Periods 
stabilization admixture. It is possible that the presence of other chemical compounds in the ESA may have interfered with the hydration process of the lime thereby slowing down the formation of the reaction products. Moreover, this happens only when ESA content is dominant in the combination. Thus, the effect of curing period on the development of ESA modified lime as well as ESA stabilized soil needs to be investigated further to clearly understand the strength gain trend.

\subsection{The Effect of ESA and Lime on the Plasticity of the Stabilized Soil}

Figure 4 shows the effect of the stabilization on the Atterberg limits of the stabilized soil. It can be seen that the replacement of lime with ESA resulted in a marginal increase in the liquid limit of the soil whereas pure ESA was able to reduce the liquid limit to a value much lower than that of pure lime stabilized soil. Coming to the plasticity limit, it can be seen that with an increase in the ESA content in the mix, there is an increase in the plastic limit of the soil. However, pure ESA stabilized soil resulted in a slightly lower plastic limit values. Based on the combined results of liquid and plastic limit, it can be seen that the increase in ESA content in the mix reduced the plasticity of the pure lime stabilized soil from $24.3 \%$ to $18.9 \%$ for pure ESA stabilized soil. It is well known that the lime results in reduction in plasticity due to ion exchange ([22],[5]), reduction in diffused double layer with increase in electrolyte concentration and viscosity of the pore fluid [29]. ESA having a similar composition of lime may have resulted in a similar behaviour. It is clear that though the ESA replacement of lime failed to produce a favourable result in terms of strength, ESA did contribute to a favourable improvement in the plasticity characteristics of the soil. Thus, it can be stated that ESA replacement can be considered where the workability of the soil needs to be improved.

\subsection{The Effect of Wetting and Drying on the UCS of Lime and ESA Stabilized Soil}

The durability performance of the stabilized soil against cycles of wetting and drying was evaluated by subjecting the specimens to one, three and five cycles of wetting and drying. Figure 5 shows the durability resistance of the various combinations to wetting and drying cycles. From the figure, it can be seen that pure lime stabilized soil, LE30, shows a drastic loss in strength after the first cycle of wetting and drying. The strength drops from $309.8 \mathrm{kPa}$ to $174.5 \mathrm{kPa}$. However, the loss in strength is more or less stabilized after 3 cycles of wetting and drying. The strength stabilizes close $161 \mathrm{kPa}$ for 3 and 5 cycles of wetting and drying. As the lime content is replaced with ESA, at low replacement levels i.e., LE21, the wetting and drying resistance is very similar to that of lime stabilized soil wherein there is a reduction in the strength of the specimens after the first cycle of wetting and drying. The strength drops from $130.7 \mathrm{kPa}$ to 69.6 $\mathrm{kPa}$. The loss in strength also stabilizes after 3 cycles of wetting and drying similar to pure lime stabilized soil LE30. The strength ranges between $34-40 \mathrm{kPa}$ between 3-5 cycles. But, as the ESA replacement increases in the mixture, there is a change in the wet-dry resistance of the specimens. For LE1.5, there is a slight increase in strength after an initial loss in strength at cycle 1 . The strength drops from $113.1 \mathrm{kPa}$ to $43.1 \mathrm{kPa}$ after the first cycle. The strength of the specimens after 3 and 5 cycles are marginally higher. The strength lies between 54.7 to $69.1 \mathrm{kPa}$ after three cycles. Combinations LE12 and LE03 show a much more cleared increase in strength after 3 cycles of wetting and drying after a marginal reduction in strength after the first cycle. Combination LE12 increases in strength from $95.6 \mathrm{kPa}$ for no cycles of wetting and drying to $133.5 \mathrm{kPa}$ for 5 cycles. Combination LE03 performs extremely well in extreme conditions to such an extent that it gains strength higher than pure lime stabilized soil after 3 cycles of wetting and drying. The

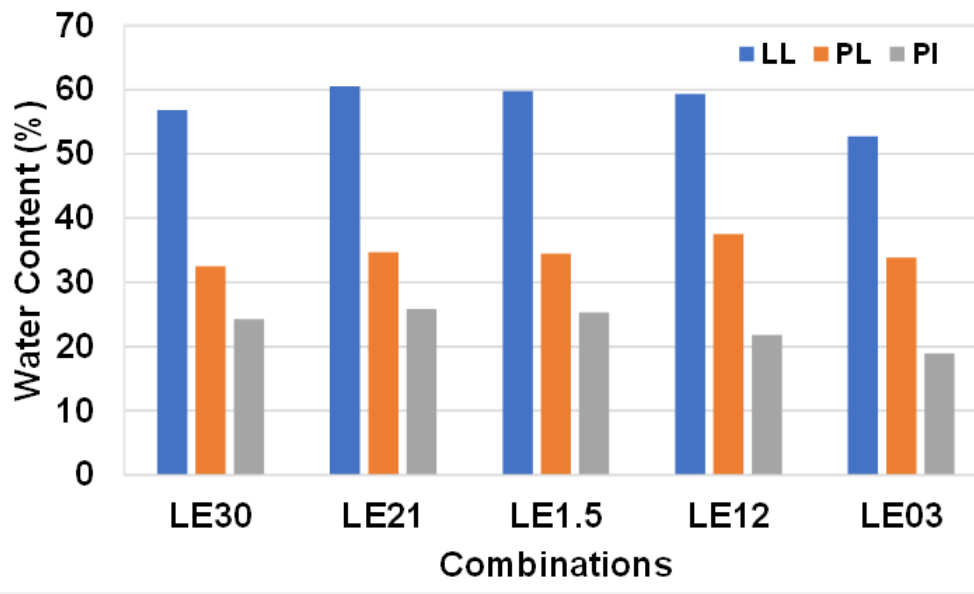

Figure 4 Effect of Lime and ESA on the Atterberg Limits 


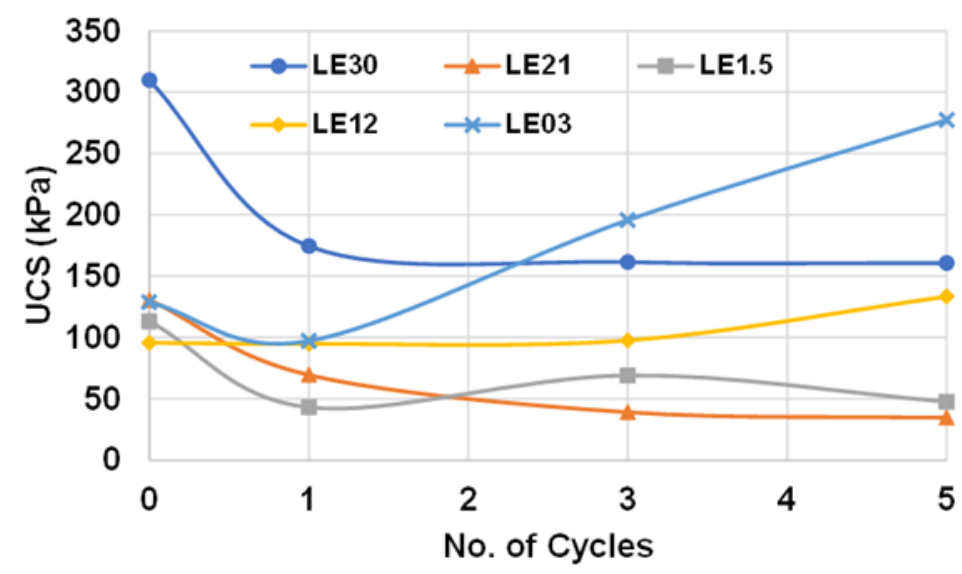

Figure 5 Wetting and Drying Resistance of ESA and Lime Stabilized Soil

trend even continues till 5 cycles of wetting and drying wherein the strength of the specimens are significantly higher than pure lime stabilized soil, LE30. The strength of LE03 increases from $128.7 \mathrm{kPa}$ for no cycles to 195.8 $\mathrm{kPa}$ and $277.4 \mathrm{kPa}$ for 3 and 5 cycles respectively. The increase in strength of the specimens may be attributed to the deficiency in water content during moulding of the specimens. The wetting and drying cycles may have supplied sufficient moisture for the specimens for hydration and progress of pozzolanic reactions to proceed further. Similar results of increase in strength with increase in number of wetting and drying cycles have been reported by other researchers as well ([1],[23]). Muntohar and Khasanah [23] attribute the increase in strength with wetting and drying cycles to two reasons. First, the increase in the duration of chemical reactions during wetting and drying cycles and second, the increase in the quantum of cementitious compounds during wetting and drying cycles. Thus, it can be stated that ESA replacement of lime in soil stabilization can be considered under extreme conditions like wetting and drying where they can perform better than pure lime stabilized soil. However, the optimum quantity of replacement cannot be concluded based on the present investigation and more studies need to be conducted to comment on the same. The variations in microstructure due to ESA replacement of lime should be studied to better understand the mechanism of strength enhancement after wetting and drying cycles.

\section{CONCLUSIONS AND RECOMMENDATIONS}

The present investigation dealt the possibility of valorization of ESA as a potential replacement for lime in stabilization of expansive soils. Based on the results of the investigations the following points can be concluded.

I. With increase in ESA replacement of lime from zero to hundred percent, the strength dropped from $309.8 \mathrm{kPa}$ to $128.7 \mathrm{kPa}$. The replacement of ICL content with increasing proportion of ESA also results in reduction of lime content below the minimum required value. Thus, it can be concluded that under normal conditions, replacement of lime with ESA leading to less than ICL content, is not a viable option.

II. From the results of the present and earlier works, it was found that ESA/lime ratio of less than one performed better when compared to higher ratios of ESA/lime. Thus, lower ESA/lime ratios are recommended when using ESA along with lime in soil stabilization.

III. ESA replacement of lime resulted in a reduction in strength after 7 days of curing, followed by further increase in strength for 28 days of curing for all combinations with ESA. This trend of strength gain with curing was unlike lime stabilization and needs to be investigated further.

IV.Increasing proportion of ESA in the stabilization mix reduced the plasticity from $24.3 \%$ to $18.9 \%$. Thus, it can be concluded that ESA under normal conditions, though not capable of strength improvement, can be considered as a soil conditioner, to improve the workability of the soil by modifying its plasticity characteristics.

$\mathrm{V}$. With increasing, proportion of ESA, the durability performance of the combinations improved when subjected to multiple cycles of wetting and drying. However, an optimal replacement content cannot be recommended based on the present investigation and more research is needed in this area. Thus, it can be concluded that the ESA replacement of lime can be considered a viable option in soil stabilization in areas prone to alternating wet and dry subsoil conditions.

The investigation only dealt with replacement of lime content below ICL. However, there are other phases of lime stabilization based on OLC which need to be investigated for its performance when replaced with ESA. Other proportions/replacements can be attempted with different curing periods to better understand the strength development and optimization of ESA content. 
[1] Anggraini, V, Asadi, A, Farzadnia, N, Jahangirian, H \& Huat, BBK 2016, 'Reinforcement benefits of nanomodified coir fiber in lime-treated marine clay', Journal of Materials in Civil Engineering, vol. 28, no. 6, pp. 1-8.

[2] ASTM 2006, D6276 Standard Test Method for Using $\mathrm{pH}$ to Estimate the Soil-Lime Proportion Requirement, vol. 14, United States, pp. 1-4.

[3] Bell, FG 1996, 'Lime stabilization of clay minerals and soils', Engineering Geology, vol. 42, no. 4, pp. 223-237.

[4] Bensaifi, E, Bouteldja, F, Nouaouria, MS \& Breul, P 2019, 'Influence of crushed granulated blast furnace slag and calcined eggshell waste on mechanical properties of a compacted marl', Transportation Geotechnics, vol. 20, no. 100244, pp. 1-9.

[5] Bhuvaneshwari, S, Robinson, RG \& Gandhi, SR 2013, 'Behaviour of Lime Treated Cured Expansive Soil Composites', Indian Geotechnical Journal, vol. 44, no. 3, pp. 278-293.

[6] BIS 1970, IS 1498 Classification and Identification of Soils for General Engineering Purposes, India, pp. 4-24.

[7] BIS 1972, IS 2720 Methods of Test for Soils:Part 6 Determination of Shrinkage Factors, India, pp. 1-12.

[8] BIS 1980, IS 2720 Methods of Test for Soils Part 3:Determination of Specific Gravity/Section 1 Fine Grained Soils, India, pp. 1-8.

[9] BIS 1983, IS 2720 Methods of Test For Soils:Part 1 - Preparation of Dry Soil Sample for Various Tests, India, pp. 1-10.

[10] BIS 1985a, IS 2720 Methods of Test for Soils:Part 4 Grain Size Analysis, India, pp. 1-38.

[11] BIS 1985b, IS 2720 Methods of Test for Soils:Part 5 Determination of Liquid and Plastic Limit, India, pp. $1-16$.

[12] BIS 1991, IS 2720 Methods of Test for Soils:Part 10 - Determination of Unconfined Compressive Strength, India, pp. 1-4.

[13] Eades, JL \& Grim, RE 1966, 'A Quick Test to Determine Lime Requirements for Lime Stabilization', Highway Research Record, vol. 139, pp. 61-72.

[14] Government of India 2018, National Action Plan for Egg \& Poultry-2022.

[15] James, J \& Pandian, PK 2013, 'Performance Study on Soil Stabilisation using Natural Materials', International Journal of Earth Sciences and Engineering, vol. 6, no. 1, pp. 194-203.

[16] James, J \& Pandian, PK 2015, 'Soil Stabilization as an Avenue for Reuse of Solid Wastes: A Review', Acta Technica Napocensis: Civil Engineering and Architechture, vol. 58, no. 1, pp. 50-76.

[17] James, J \& Pandian, PK 2016, 'Development of Early Strength of Lime Stabilized Expansive Soil: Effect of Red Mud and Egg Shell Ash', Acta Technica Corviniensis - Bulletin of Engineering, vol. 9, no. 1, pp. 93-100.

[18] James, J, Pandian, PK, Deepika, K, Venkatesh, JM, Manikandan, V \& Manikumaran, P 2016, 'Cement Stabilized Soil Blocks Admixed with Sugarcane Bagasse Ash', Journal of Engineering, vol. 2016, no. Article ID 7940239, pp. 1-9.
[19] James, J, Pandian, PK \& Switzer, AS 2017, 'Egg Shell Ash as Auxiliary Addendum to Lime Stabilization of an Expansive Soil', Journal of Solid Waste Technology and Management, vol. 43, no. 1, pp. 15-25.

[20] James, J \& Saraswathy, R 2020, 'Performance of Fly Ash - Lime Stabilized Lateritic Soil Blocks Subjected to Alternate Cycles of Wetting and Drying', Civil and Environmental Engineering, vol. 16, no. 1, pp. 30-38

[21] Kampala, A, Horpibulsuk, S, Prongmanee, N \& Chinkulkijniwat, A 2014, 'Influence of wet-dry cycles on compressive strength of calcium carbide residuefly ash stabilized clay', Journal of Materials in Civil Engineering, vol. 26, no. 4, pp. 633-643.

[22] Little, DN 1995, Handbook for Stabilization of Pavement Subgrades and Base Courses with Lime, Austin, Texas.

[23] Muntohar, AS \& Khasanah, IA 2019, 'Effect of moisture on the strength of stabilized clay with limerice husk ash and fibre against wetting-drying cycle', International Journal of Integrated Engineering, vol. 11, no. 9 Special Issue, pp. 100-109.

[24] Nasrizar, AA, llamparuthi, K \& Muttharam, M 2012, 'Quantitative Models for Strength of Lime Treated Expansive Soil', in GeoCongress 2012, March 2529, American Society of Civil Engineers, Oakland, California, US, pp. 978-987.

[25] Okonkwo, UN, Odiong, IC \& Akpabio, EE 2012, 'The Effects of Eggshell Ash on the Strength Properties of Cement Stabilized Lateritic', International Journal of Sustainable Construction Engineering \& Technology, vol. 3, no. 1, pp. 18-25.

[26] Phanikumar, BR, Manvita, C \& Patnaik, R 2011, 'Influence of Wetting-Drying Cycles on Heave Behaviour of Fiber-Reinforced Expansive Soil Specimens', in Proceedings of the Indian Geotechnical Conference 2011, December 15-17, Kochi, India, pp. 505-507.

[27] Saraswathy, R, James, J, Pandian, PK, Sriram, G, Sundar, JK, Kumar, GS \& Kumar, AS 2019 'Valorization of Crushed Glass as a Potential Replacement for Sand in Cement Stabilized Fly Ash Bricks', Civil and Environmental Engineering, vol. 15, no. 1, pp. 48-57.

[28] Singh, A \& Punmia, BC 1965, 'A New Laboratory Compaction Device and its Comparison with the Proctor Test', Highway Research News, vol. 17, pp. 37-41.

[29] Sivapullaiah, P V. \& Jha, AK 2014, 'Gypsum Induced Strength Behaviour of Fly Ash-Lime Stabilized Expansive Soil', Geotechnical and Geological Engineering, vol. 32, no. 5, pp. 12611273.

[30] Yilmaz, F \& Fidan, D 2017, 'Effect of Wetting-Drying on the Volumetric Stability of Clayey Soil Stabilized with Lime and Perlite', European Journal of Technique, vol. 7, no. 2, pp. 207-218. 


\section{VALORISATION OF EGG SHELL ASH AS A POTENTIAL REPLACEMENT FOR LIME IN STABILIZATION OF EXPANSIVE SOILS}

\author{
Jijo JAMES \\ K. JOTHI PRIYA \\ P. KARTHIKA \\ S. KOKILA \\ V. VIDYASAGAR
}

The investigation focussed on the possibility of replacing lime in soil stabilization using Egg Shell Ash (ESA), a waste derived from poultry industry. An expansive soil was characterized for its properties in the lab. The minimum lime content required for modification of soil properties was determined from the Eades and Grim $\mathrm{pH}$ test. This lime content came out to be $3 \%$. The lime content was replaced using ESA in the proportions of $33 \%, 50 \%, 67 \%$ and $100 \%$. Unconfined compression test specimens of dimension $38 \mathrm{~mm} \times 76 \mathrm{~mm}$ were cast for different combinations and were cured for periods of 3, 7 and 28 days. Samples were also subjected to 1, 3 and 5 cycles of wetting and drying to understand its durability. After the designated curing periods and cycles of wetting and drying, they were strained axially till failure. Atterberg limits tests were done to determine the plasticity of the stabilized soil. The strength results indicated that ESA cannot be used under normal conditions as a replacement for lime, however, ESA replacement resulted in good durability of the specimens under conditions of wetting and drying. It was concluded that ESA replacement of lime can be adopted in conditions of wetting and drying.

Key words: Expansive soil, lime, egg shell ash, stabilization, strength, durability.

\section{VREDENOVANJE PEPELA OD LJUSKE JAJETA KAO POTENCIJALNA ZAMENA KREČA U STABILIZACIJI EKSPANZIVNIH TLA}

\author{
Jijo JAMES \\ K. JOTHI PRIYA \\ P. KARTHIKA \\ S. KOKILA \\ V. VIDYASAGAR
}

Predmet ovog istraživanja odnosi se na mogućnost zamene kreča pri stabilizaciji tla korišćenjem pepela ljuske jaja (ESA), otpadnog nusproizvoda koji se dobija iz živinarstva. U tu svrhu laboratorijski su ispitana svojstva ekspanzivnog tla. Minimalni sadržaj kreča koji je neophodan za modifikaciju svojstava tla određen je na osnovu Eades-Grimovog pH testa. Test je pokazao da je količina neophodnog kreča $3 \%$. Sadržaj kreča je zamenjen pepelom ljuske jaja (ESA) u proporcijama od $33 \%, 50 \%, 67 \%$ i $100 \%$. Odliveni su neutegnuti uzorci dimenzija $38 \mathrm{~mm} \times 76 \mathrm{~mm}$, namenjeni za testiranje čvrstoće pri različitim kombinacijama, koji su ostavljeni da se suše 3,7 odnosno 28 dana. Da bi se odredila njihova trajnost, uzorci su podvrgnuti 1,3 i 5 ciklusa vlaženja i sušenja. Nakon odgovarajućih perioda stvrdnjavanja i ciklusa vlaženja i sušenja, uzorci su podvrgnuti delovanju aksijalne sile do loma. Plastičnost stabilizovanog tla određena je primenom testa Aterbergovih granica. Rezultati ispitivanja čvrstoće pokazali su da se u normalnim uslovima ESA ne može koristiti kao zamena za kreč, međutim, zamena kreča ESA-om rezultirala je dobrom izdržljivošću uzoraka u uslovima vlaženja i sušenja. Zaključeno je da se kreč može zameniti ESA-om u uslovima vlaženja i sušenja.

Ključne reči: ekspanzivno tlo, kreč, pepeo od ljuske jaja, stabilizacija, čvrstoća, trajnost 